\title{
Analysis the Implementation of the Webbed Type Integrative Thematic Learning Approach in 2013 Curriculum Context in Elementary School 1 Sukarame Bayongbong Garut
}

\author{
Neni Nadiroti Muslihah, Risma Nuriyanti, Siti Ropah Purnamasari, Ejen Jenal \\ Mutaqin
}

Institut Pendidikan Indonesia

neninadiroti@institutpendidikan.ac.id

Article History

accepted 05/11/2020

approved 10/11/2020

published 01/02/2021

\begin{abstract}
This study aims to describe the related planning, implementation, assessment, and obstacles the webbed type integrative thematic learning approach. This research uses a qualitative approach. Data collection techniques using observation, interviews, and documentation. Data analysis used the Miles and Huberman model, namely data reduction, data display and conclusions. The results showed that (1) the webbed type integrating thematic learning planning that was carried out was in accordance with the Indonesian Minister of Education and Culture Regulation No. 22/2016 on Basic and Secondary Education Process Standards. (2) the implementation of webbed type integrative thematic learning the teacher has carried out the three stages, namely preliminary activities, core activities and closing activities. (3) assessment of the webbed type of integrated thematic learning in the teacher learning process using observation sheets and assessment reflections, while the assessment at the end of teacher learning uses written tests and oral tests. (4) the obstacles experienced by the teacher, namely the determination of time allocation, the delivery of material in class I that is not in accordance with the situation and condition of the students, the teacher must be able to understand the methods and strategies
\end{abstract}

Keywords: thematic learning approach, webbed type, curriculum 2013

\begin{abstract}
Abstrak
Penelitian ini bertujuan untuk mendeskripsikan perencanaan, pelaksanaan, penilaian, dan hambatan pendekatan pembelajaran tematik integratif tipe webbed. Penelitian ini menggunakan pendekatan kualitatif. Teknik pengumpulan data menggunakan observasi, wawancara, dan dokumentasi. Analisis data menggunakan model Miles and Huberman yaitu reduksi data, data display dan kesimpulan. Hasil penelitian menunjukkan bahwa (1) perencanaan pembelajaran tematik integartif tipe webbed yang dilakukan sudah sesuai dengan Permendikbud RI No. 22/2016 tentang Standar Proses Pendidikan dasar dan Menengah. (2) pelaksanaan pembelajaran tematik integratif tipe webbed guru sudah melakukan ketiga tahapan yakni kegiatan pendahuluan, kegiatan inti dan kegiatan penutup. (3) penilaian pembelajaran tematik integartif tipe webbed pada proses pembelajaran guru menggunakan lembar pengamatan dan penilaian refleksi, sedangkan penilaian pada akhir pembelajaran guru menggunakan tes tulis dan tes lisan. (4) hambatan yang dialami guru yaitu penentuan alokasi waktu, penyampaian materi pada kelas I yang tidak sesuai dengan situasi dan kondisi siswa, guru harus mampu memahami metode dan strategi.
\end{abstract}

Kata kunci: pendekatan pembelajaran tematik, tipe webbed, kurikulum 2013

Social, Humanities, and Education Studies (SHEs): Conference Series https://jurnal.uns.ac.id/shes

p-ISSN 2620-9284

e-ISSN 2620-9292 


\section{PENDAHULUAN}

Pada zaman sekarang seiring dengan semakin berkembangnya ilmu pengetahuan dan teknologi, proses pembelajaran di Sekolah Dasar (SD) tidak hanya berdiri di depan kelas berceramah tentang materi yang ada di buku panduan. Namun lebih dari itu, guru harus memiliki keterampilan atau kompetensi untuk menunjang peran dan tanggung jawabnya sebagai guru. Salah satu pembuktiannya yaitu bagaimana guru menciptakan proses pembelajaran dengan menghadapi berbagai karakter, bakat dan minat anak yang beragam agar dapat mencapai target kompetensi yang hendak dicapai. Menurut (Sumantri, 2016, hlm. 2) menyatakan bahwa siswa di tingkat satuan pendidikan dasar khususnya SD, selain memiliki banyak keunikan juga punya banyak hal yang menarik untuk di kaji secara keilmuan, baik secara psikologis maupun budaya dari aspek psikologi perkembangan yang tentunya akan berimplikasi pada bagaimana proses pembelajaran di SD.

Alasan rasional dalam kaitan tersebut diungkapkan pula oleh Rusman (2012, hlm. 250) bahwa "Tahap perkembangan tingkah laku belajar Sekolah Dasar (Madrasah Ibtidaiyah) sangat dipengaruhi oleh aspek-aspek dari dalam dirinya dan lingkungan yang ada di sekitarnya". Kedua hal tersebut tidak mungkin dipisahkan karena memang proses belajar terjadi dalam konteks interaksi diri siswa dengan lingkungannya. Sementara itu, menurut Piaget (dalam Rusman, 2016, hlm. 142) menyatakan bahwa :

Setiap anak memiliki struktur kognitif yang disebut schemata yaitu sistem konsep yang ada dalam pikiran sebagai hasil pemahaman terhadap objek yang ada dalam lingkungannya. Pemahaman tentang objek tersebut berlangsung melalui proses asimilasi, yaitu menghubungkan objek dengan konsep yang sudah ada dalam pikiran anak dan akomodasi, yaitu proses memanfaatkan konsep-konsep dalam pikirannya untuk menafsirkan objek yang dilihatnya.

Pendapat di atas sejalan dengan berbagai kebijakan Peraturan Pemerintah Nomor 32 Tahun 2013 tentang Perubahan Atas Peraturan Pemerintah No. 19 Tahun 2005 tentang Standar Nasional Pendidikan Pasal 19 ayat (1) berbunyi "Proses pembelajaran pada satuan pendidikan diselenggarakan secara interaktif, inspiratif, menyenangkan, menantang, memotivasi peserta didik untuk berpartisiasi aktif, serta memberikan ruang yang cukup bagi prakarsa, kreativitas, dan kemandirian sesuai dengan bakat, minat, dan perkembangan fisik serta psikologis peserta didik" (Prastowo, 2016, hlm. 128). Serta UU Nomor 20 Tahun 2003 tentang Sistem Pendidikan Nasional Bab V Pasal 1-b yang menyatakan bahwa "Setiap peserta didik pada setiap satuan pendidikan berhak mendapatkan pelayanan pendidikan sesuai dengan bakat, minat dan kemampuannya." (Trianto, 2009, hlm. 105).

Mengingat pada fungsi dan tujuan dari kebijakan dan peraturan pada landasan yuridis bahwa jelaslah proses pembelajaran secara terpadu (integratif) memungkinkaan siswa untuk belajar secara utuh (holistik) terhadap kajian suatu materi pembelajaran. Bertemali dengan definisi pembelajaran integratif, Kemendikbud (dalam Abidin, 2014, hlm. 210) menyatakan bahwa pembelajaran tematik terpadu merupakan pendekatan pembelajaran yang mengintegrasikan berbagai kompetensi dari berbagai mata pelajaran ke dalam berbagai tema. Sementara itu, menurut Anitah (dalam Trianto, 2009, hlm. 81) menyatakan, bahwa pembelajaran terpadu merupakan konsep yang menggunakan pendekatan pembelajaran yang melibatkan beberapa konsep secara terpadu sehingga memfasilitasi siswa untuk terlibat serta mendorong siswa memahami konsep melalui pengalaman langsung dan menghubungkan dengan pengalaman-pengalaman nyata dalam proses pembelajaran

Berdasarkan beberapa pendapat di atas dapat peneliti simpulkan bahwa pembelajaran integratif merupakan pembelajaran yang memadukan berbagai bentuk pemaduan baik pemaduan materi pembelajaran, pemaduan pengalaman belajar, dan pemaduan keterampilan, tema, konsep, dan topik lintas disiplin ilmu. 
Secara filosofis, kemunculan pembelajaran tematik integratif sangat dipengaruhi oleh tiga aliran filsafat berikut: (1) progresivisme, (2) kontruktivisme, dan (3) humanisme. Aliran progresivisme memandang proses pembelajaran perlu ditekankan pada pembentukan kreativitas, pemberian sejumlah kegiatan, suasana yang alamiah (natural), dan memerhatikan pengalaman siswa. Aliran kontruktivisme melihat pengalaman langsung siswa sebagai kunci dalam pembelajaran. Sementara aliran humanisme melihat siswa dari segi keunikan/kekhasannya, potensinya dan motivasi yang dimilikinya (Rusman, 2012, hlm. 255). Sejalan dengan pendapat Sumantri (2016, hlm.

2) menyatakan bahwa proses pembelajaran yang baik dan bermutu hendaknya mengedepankan aspek siswa sebagai subjek pembelajaran itu sendiri. Maka dapat peneliti simpulkan bahwa jelaslah implementasi proses pembelajaran di SD melalui pembelajaran integratif merupakan satu

alternatif yang dapat di kembangkan dan dilaksanakan secara terus menerus.

Menurut Fogarty (1991, hlm. 61) terdapat sepuluh model dalam merencanakan pembelajaran terpadu. Dari kesepuluh model tersebut ada 3 model pembelajaran terpadu yang dipilih dan dikembangkan di program Pendidikan Guru Sekolah, yaitu model keterhubungan (connected), model jaring laba-laba (webbed), dan model keterpaduan (Majid, 2014, hlm. 76).

Sebagai suatu pendekatan pembelajaran di era zaman sekarang, pendekatan pembelajaran tematik integratif tidak mudah untuk dilaksanakan, karena memerlukan penyesuaian diri dan kemauan khususnya bagi para pendidik dan tenaga kependidikan untuk beradaptasi. Hal ini mengingat, bahwa pendekatan pembelajaran tematik yang memadukan berbagai disiplin ilmu memerlukan proses perencanaan pembelajaran yang cukup baik dan kompleks. Menurut Sumantri (2016, hlm. 21) mengemukakan bahwa perencanaan memegang peran penting dalam menentukan arah dan tujuan dari pembelajaran yang akan dilaksanakan. Proses pembelajaran memegang peran penting dalam mengimplementasikan perencanaan yang telah dibuat. Tetapi pada

kenyataannya,proses pembelajaran di SD dilaksanakan dengan mengacu pada materi yang harus dikejar sesuai deadline waktu yang telah ditentukan dalam program tahunan maupun program semester. Hal tersebut sudah jelas akan meninggalkan esensi proses pembelajaran itu sendiri yang memandang siswa sebagai subjek pembelajaran.

Pernyataan tersebut sesuai dengan hasil observasi dan wawancara yang dilakukan dengan salah satu Guru Kelas 1 yaitu pada tanggal 25 Juli 2019 di SD Negeri I Sukarame menyatakan bahwa

masih sulit untuk menjadikan siswa sebagai subjek dalam proses pembelajaran tematik di karenakan masih kurangnya pemahaman guru dalam hal penyusunan dan perencanaan prosedur, pelaksanaan pembelajaran yang tidak sesuai dengan Rencana Pelaksanaan Pembelajaran (RPP), serta melakukan penilaian autentik yang tidak mudah bagi pendidik, sehingga pendidik belum siap dalam mengaplikasikan prosedur yang telah ditentukan.

Menurut Rusman (2012, hlm. 260) menyatakan bahwa keberhasilan pelaksanaan pembelajaran tematik dipengaruhi oleh seberapa jauh pembelajaran tersebut direncanakan sesuai dengan kondisi dan potensi siswa (minat, bakat, kebutuhan dan kemampuan). Dikatakan Majid (2014, hlm. 89) yang menyatakan bahwa karakteristik pembelajaran terpadu antara lain siswa pembelajaran berpusat pada siswa, memberikan pengalaman langsung, pemisahan mata pelajaran tidak begitu jelas, menyajikan konsep dari berbagai mata pelajaran, bersifat fleksibel dan menggunakan prinsip belajar sambil bermain dan menyenangkan. Berdasarkan pandangan tersebut, dapat diyakini bahwa cara belajar siswa SD yang masih saling mengaitkan satu tema dengan tema lainnya akan lebih mudah dalam belajar apabila materi pembelajaran dipelajari secara terpadu dengan mengaitkan konsep satu dengan lainnya yang 
memiliki keterhubungan. Hal tersebut di dukung salah satunya yaitu dengan penggunaan pendekatan pembelajaran terpadu dengan model tipe webbed, karena model tersebut menyajikan pendekatan tematik integratif untuk mengintegrasikan mata pelajaran.

Berdasarkan semua pemaparan di atas, maka dirasa penting untuk melakukan penelitian pembelajaran tematik integratif tipe webbed sebagai suatu pendekatan dalam proses pembelajaran yang memerlukan banyak persiapan dalam penerapannya. Dengan demikian, untuk merealisasikan rencana tersebut maka peneliti mengajukan judul "Analisis Implementasi Pendekatan Pembelajaran Tematik Integratif Tipe Webbed dalam Konteks Kurikulum 2013 di SDN 1 Sukarame Kecamatan Bayongbong Garut."

\section{METODE}

Penelitian ini menggunakan pendekatan kualitatif. Dalam penelitian ini, peneliti bermaksud untuk mendeskripsikan implementasi model pembelajaran tematik integratif tipe webbed dalam konteks kurikulum 2013 di SDN 1 Sukarame Kecamatan Bayongbong. Jenis penelitian ini melibatkan subjek manusia sebagai sumber pengumpulan datanya. Data diperoleh dari wawancara dan dokumentasi. Wawancara diajukan pada informan yang memiliki pengetahuan mengenai permasalahan yang akan diteliti. Data lisan berupa wawancara dengan kepala sekolah, guru kelas I, guru kelas IV dan siswa di SDN 1 Sukarame Kecamatan Bayongbong. Pengambilan Sumber data dilakukan dengan cara purposive yaitu teknik pengambilan sumber data dengan pertimbangan tertentu.

Pengambilan sumber data juga dilakukan dengan cara snowball yaitu teknik pengambilan sumber data yang pada awalnya jumlahnya sedikit, lama- lama menjadi besar (Sugiyono, 2016, hlm. 218). Sementara itu, teknik pengumpulan data yang dilakukan adalah dengan menggunakan observasi, wawancara daan dokumentasi. Sedangkan Analisis data dalam penelitian kualitatif, dilakukan pada saat pengumpulan data berlangsung, dan setelah selesai pengumpulan data dalam periode tertentu. Pada saat wawancara, peneliti sudah melakukan analisis terhadap jawaban yang di wawancarai. Peneliti melakukan tiga kegiatan analisis data secara serempak, yaitu data reduction, data display, dan conclusion drawing/verification (Miles dan Hubberman dalam Yusuf, 2014, hIm. 407).

\section{HASIL DAN PEMBAHASAN}

Mewujudkan proses pembelajaran secara utuh dan sesuai dengan tujuan pendidikan maka perlu adanya perancangan pembelajaran yang berorientasi pada pendekatan pembelajaran tematik integratif dengan tipe webbed yang diterapkan pada satuan pendidikan sekolah dasar pada umumnya. Hal tersebut senada dengan teori yang diungkapkan oleh Rusman (2016, hlm. 155) mengatakan bahwa keberhasilan pelaksanaan pembelajaran tematik dipengaruhi oleh seberapa jauh pembelajaran tersebut direncanakan sesuai dengan kondisi dan potensi siswa (minat, bakat, kebutuhan dan kemampuan).

Perencanaan menurut Majid (2012, hlm. 15) adalah menyusun langkah-langkah yang akan dilaksanakan untuk mencapai tujuan yang telah ditentukan, namun perencanaan yang dibuat harus dapat dilaksanakan dengan mudah dan tepat sasaran. Hal tersebut menjadi sangat penting untuk kita ketahui sebagai pendidik secara khusunya.Hasil dari penelitian di lapangan yaitu di SDN I Sukarame Kabupaten Garut pada guru kelas I dan IV mengenai perencanaan pembelajaran tematik integratif tipe webbed. Perencanaan pembelajaran dirancang dalam bentuk silabus dan Rencana Pelaksanaan Pembelajaran (RPP) yang mengacu pada Standar isi. Perencanaan Pembelajaran meliputi penyusunan rencana pelaksanaan pembelajaran dan penyiapan media, dan sumber media, perangkat penilaian pembelajaran,dan scenario 
pembelajaran. Penyusunan RPP, guru mengacu pada silabus dan standar isi maupun buku pegangan guru untuk menyesuaikan dengan materi yang akan disampaikan. Hal tersebut juga sesuai dengan Permendikbud RI No. 22/2016 tentang Standar Proses Pendidikan dasar dan Menengah yang menyatakan bahwa "Perencanaan pembelajaran dirancang dalam bentuk silabus dan RPP yang mengacu pada Standar Isi".

Dalam pelaksanaan pembelajaran secara umum terbagi menjadi 3 tahapan yaitu tahap pendahuluan atau kegiatan awal, tahap kedua atau kegiatan inti dan tahap ketiga adalah kegiatan penutup atau kegiatan akhir. Berdasarkan hasil wawancara maupun observasi yang peneliti lakukan pada proses pembelajaran luring, pelaksanaan proses pembelajaran tematik integratif tipe webbed secara umum guru sudah melakukan 3 tahap kegiatan yaitu kegiatan pembuka, kegiatan inti dan kegiatan penutup. Guru mengawali pembelajaran dengan menyiapkan peserta didik secara psikis dan fisik, serta pemberian apersepsi, penyampaian tema dan tujuan pembelajaran pada saat proses pelaksanaan pembelajaran. Dalam kegiatan inti guru juga menggunakan metode, media, pendekatan serta sumber belajar untuk menunjang proses pembelajaran agar berjalan efektif dan efisien serta bermakna. Sedangkan pada kegiatan penutup guru bersama siswa menyimpulkan materi, memberikan umpan balik serta tindak lanjut baik dalam bentuk pemberian tugas kelompok maupun individu. Implementasi Kurikulum 2013 dengan pendekatan pembelajaran tematik integratif tipe webbed, menurut Permendikbud RI No. 22 Tahun 2016 tentang Standar Proses Pendidikan Dasar dan Menengah menyatakan bahwa ciri-ciri kegiatan intinya diungkapkan sebagai berikut, yaitu: menggunakan model pembelajaran, metode pembelajaran, media pembelajaran, dan sumber belajar yang disesuaikan dengan karakteristik peserta didik dan mata pelajaran.

Aktivitas guru dalam proses pelaksanaan pembelajaran dengan pendekatan pembelajara tematik integartif tipe webbed dalam konteks kurikulum 2013 secara keseluruhan pada kelas I dan IV dapat disimpulkan memiliki kategori sangat baik untuk masing-masing kelas. Pada kelas I mendapat rata-rata persentase sebesar $93 \%$ dan kelas IV mendapat rata-rata persentase $88 \%$. Salah satu penekanan dalam kurikulum 2013 adalah penilaian autentik, yakni kegiatan menilai peserta didik yang menekankan pada apa yang seharusnya dinilai, baik proses maupun hasil penilaian yang disesuikan dengan tuntutan kompetensi yang ada yang dilakukan oleh guru. penilaian yang dilakukan di SDN I Sukarame tidak terlepas dari prinsip-prinsip penilaian yaitu penilaian harus merujuk pada SK dan KD, objektif, bisa dipahami, dan penilaian harus secara terus menerus dilakukan. Aspek yang dinilai oleh guru kelas di SDN I Sukarame yaitu aspek spiritual, sosial, pengetahuan dan keterampilan. Penilaian yang dikembangkan dalam pembelajaran tematik terpadu di SD/MI meliputi prosedur yang digunakan, jenis dan bentuk penilaian, serta alat evaluasi yang digunakan. Penilaian tersebut disesuaikan dengan penilaian autentik atau Autentic Asessment, yaitu dalam bentuk penilaian proyek, penilaian portofolio, penilaian kinerja dan tes (Rusman, 2016, hlm. 179).

Sementara itu, alat penilaian yang dilakukan di SDN I Sukarame pada kelas I maupun kelas IV adalah tes dan non tes baik berupa latihan soal, fortopolio, dan lembar kegiatan produk maupun proyek. Hal tersebut juga sesuai dengan permendikbud no 22 tahun 2016 bahwa pada evaluasi pembelajaran tematik yaitu dengan evaluasi proses pembelajaran yang meliputi lembar pengamatan, angket sebaya, rekaman, catatan anekdot, dan refleksi sedangkan evaluasi hasil pembelajaran meliputi tes lisan dan tes tulis. Namun berdasarkan hasil observasi maupun dokumentasi yang peneliti lakukan, pada kenyataannya guru hanya menggunakan evalusi lembar pengamatan, tes tulis dan tes lisan untuk instrumen yang lainnya guru tidak menggunakan. 
Hambatan yang dialami guru dalam tahap perencanaan adalah penentuan alokasi waktu yang harus di sesuaikan dengan kondisi dan situasi siswa itu sendiri. Dalam proses pelaksanaan pembelajaran juga seorang guru harus mampu memahami dan mengetahui strategi saat proses belajar mengajar, karena hal tersebut juga menjadi hambatan dalam proses pengamalan tersebut sewaktu proses belajar mengajar di dalam kelas. Sementara, kendala yang dihadapi dalam proses penilaian yakni secara umumya diketahui bahwa pada masa awal semester I masih banyak siswa kelas I yang belum bisa membaca dengan baik dan benar.

Berdasarkan data yang diperoleh, maka dapat peneliti simpulkan bahwa implementasi kurikulum 2013 di SDN I Sukarame telah diterapkan pada tahun ajaran 2014/2015 untuk jenjang kelas I dan kelas IV. Persiapan yang sekolah lakukan untuk implementasi kurikulum 2013 yaitu dengan mengikuti diklat- diklat, pelatihan-pelatihan, sosialisasi guru, tutor sebaya, workshop.

Persiapan yang dilakukan oleh pihak sekolah tersebut, sesuai dengan teori yang dikemukakan oleh Prastowo (2017, hlm. 9) bahwa pada tahun 2013/2014, Kementrian Agama melakukan persiapan implementasi kurikulum 2013 dalam bentuk pelatihan-pelatihan kepala madrasah, pengawas madrasah, pendidik, serta pengadaan bahan ajar dan buku pedoman guru. Kurikulum 2013 menggunakan pendekatan tematik integratif dengan berbagai tipe/model yang diterapkan, beberapa teori menyebutkan bahwa terdapat 10 model pada pembelajaran tematik integratif. Dari

10 pendekatan pembelajaran tematik integratif guru cukup mengenal model tersebut. Adapun model tematik integratif yang dipakai oleh satuan pendidikan sekolah dasar yaitu model webbed dan integrated. Sementara, tipe pendekatan pembelajaran tematik integratif yang diimplementasikan di SDN I Sukarame adalah model webbed. Berdasarkan teori menurut Majid (2014, hlm. 76) bahwa dari kesepuluh model tersebut ada 3 model pembelajaran terpadu yang dipandang layak untuk dikembangkan dan mudah dilaksanakan pada pendidikan formal (sekolah dasar), yaitu model

keterhubungan (connected), model jaring laba-laba (webbed), dan model keterpaduan (integrated). Namun setelah peneliti melakukan penelitian, peneliti menemukan bahwa SDN I Sukarame hanya menggunakan 2 model saja yakni model webbed dan model integrated karena sudah jelas diaplikasikan dalam pembelajaran pada kurikulum 2013.

\section{SIMPULAN}

Dari hasil observasi, wawancara serta didukung pula pengkajian analisis dokumentasi yang peneliti lakukan, maka dapat disimpulkan bahwa pengimlementasian pendekatan pembelajaran tematik integratif pada perencanaan, pelaksanaan dan penilaian pendekatan pembelajaran tematik integratif tipe webbed telah memenuhi standar Permendikbud RI No. 22 Tahun 2016 tentang standar proses pendidikan dasar. Saran yang diberikan adalah guru bersama kepala sekolah hendaknya mengembangkan pengetahuan tentang implementasi pendekatan pembelajaran tematik integartif tipe webbed maupun dengan tipe yang lainnya, agar terciptanya pembelajaran yang sesuai dengan situasi dan kondisi siswa sesuai dengan tujuan pendidikan itu sendiri baik dalam segi perencanaan, pelaksanaan maupun penilaian.

\section{DAFTAR PUSTAKA}

Abidin, Y. (2014). Desain Sistem Pembelajaram dalam Konteks kurikulum 2013. Bandung: PT. Refika Aditama.

Fogarty, R. (1991). Ten ways to integrate curriculum. Educational leadership, 49(2), 61-65. 
Majid, A. (2012). Perencanaan Pembelajaran: Mengembangkan Standar Kompetensi Guru. Cetakan kesembilan. Bandung: Remaja Rosdakarya

Majid, A. (2014). Pembelajaran Tematik Terpadu. Bandung: Remaja Rosdakarya

Prastowo, A. (2016). Pengembangan Bahan Ajar Tematik: Tinjauan Teoritis dan Praktik Edisi Kedua. Jakarta: Kencana

Prastowo, A. (2019). Analisis Pembelajaran Terpadu. Jakarta: Kencana

Prastowo, A. (2017). Menyusun Rencana Pelaksanaan Pembelajaran (RPP) Tematik Terpadu. Jakarta: Kencana

Rusman. (2012). Model-Model Pembelajaran Edisi Kedua. Jakarta: PT. RajaGrafindo Persada.

Rusman. (2016). Pembelajaran Tematik Terpadu. Jakarta: PT RajaGrafindo Persada.

Sugiyono. (2016). Metode Penelitian Kuantitatif, Kualitatif, dan R\&D. Bandung: Alfabeta.

Sumantri, M.S. (2016). Model Pembelajaran Terpadu di Sekolah Dasar. Jakarta: PT. RajaGrafindo Persada.

Trianto. (2009). Mengembangkan Model Pembelajaran Tematik. Jakarta: PT. Prestasi Pusatkarya.

Trianto. (2017). Desain Pengembangan Pembelajaran Tematik Bagi Anak Usia Dini TK/RA \& Kelas Awal SD/MI. Jakarta: Kencana Prenadamedia Group 